\title{
Heavy metal ion concentration in the amniotic fluid of preterm and term pregnancies from two cities with different industrial output
}

\author{
RADU IONUT NEAMTU ${ }^{1 *}$, MARIUS CRAINA $^{1 *}$, GEORGE DAHMA $^{1}$, ALIN VIOREL POPESCU $^{1}$, \\ ADELINA GEANINA ERIMESCU ${ }^{1}$, IOANA CITU ${ }^{2}$, AMADEUS DOBRESCU ${ }^{3}$, FLORIN GEORGE HORHAT ${ }^{4,5}$, \\ DAN DUMITRU VULCANESCU ${ }^{4,5}$, FLORIN GORUN ${ }^{1}$, \\ ELENA SILVIA BERNAD ${ }^{2}$, ANDREI MOTOC ${ }^{1,6}$ and IOAN COSMIN CITU ${ }^{1}$
}

\begin{abstract}
Departments of ${ }^{1}$ Obstetrics-Gynecology and Neonatology, ${ }^{2}$ Internal Medicine I and ${ }^{3}$ Surgery; ${ }^{4}$ Multidisciplinary Research Center on Antimicrobial Resistance (Multi-Rez), Microbiology Department, 'Victor Babes' University of Medicine and Pharmacy, 300041 Timisoara; ${ }^{5}$ Clinical Laboratory, 'Louis Turcanu' Emergency Hospital for Children, 300011 Timisoara; ${ }^{6}$ Department of Anatomy and Embryology, 'Victor Babes' University of Medicine and Pharmacy, 300041 Timisoara, Romania
\end{abstract}

Received October 11, 2021; Accepted November 10, 2021

DOI: $10.3892 / \mathrm{etm} .2021 .11034$

\begin{abstract}
The growth and development of the fetus is a complex phenomenon that can be influenced by several variables. High quantities of heavy metal ions in the amniotic fluid have been linked to poor health, especially in industrial, polluted and poor areas. The aim of the present study was to assess the differences in the concentration of these ions between preterm (weeks 15-37) and term pregnancies (starting at week 37). Another objective was to compare pregnancies from two cities with different industry levels. Two sample lots from two Romanian cities were analyzed. A total of 100 patients from Timisoara were compared with 60 from Petrosani, a heavy industry city in Romania. Demographic data were collected, and amniocentesis was performed on all women. Lead $(\mathrm{Pb})$, copper $(\mathrm{Cu})$, nickel $(\mathrm{Ni})$, cadmium $(\mathrm{Cd})$, arsenic (As), iron $(\mathrm{Fe})$ and zinc $(\mathrm{Zn})$ concentrations were assessed. Descriptive and analytical statistics were performed using the Mann-Whitney U test for non-parametric data and the Fisher's exact test for categorical data. In addition, categorical data was represented graphically. In the Timisoara cohort, the differences in heavy metal concentrations between preterm and term pregnancies were not statistically significant. In the Petrosani
\end{abstract}

Correspondence to: Professor Florin George Horhat, Multidisciplinary Research Center on Antimicrobial Resistance (Multi-Rez), Microbiology Department, 'Victor Babes' University of Medicine and Pharmacy, 2 Eftimie Murgu Square, 300041 Timisoara, Romania

E-mail: horhat.florin@umft.ro

${ }^{*}$ Contributed equally

Key words: amniotic fluid, heavy metals, ions, preterm, term, pregnancy, amniocentesis, heavy industry cohort, however, the concentrations of $\mathrm{Zn}(\mathrm{P}=0.02606)$ and $\mathrm{Cd}$ $(\mathrm{P}=0.01512)$ were higher in preterm than in term pregnancies. When comparing the two cohorts as a whole, the concentration of $\mathrm{Pb}(\mathrm{P}=0.04513), \mathrm{Cd}(\mathrm{P}=0.00002), \mathrm{As}(\mathrm{P}=0.03027)$ and $\mathrm{Zn}$ $(\mathrm{P}<0.00001)$ were higher in the patients from Petrosani than in those from Timisoara. Only $\mathrm{Cu}$ concentrations were higher in the Timisoara cohort $(\mathrm{P}<0.00001)$. The concentrations of $\mathrm{Ni}(\mathrm{P}=0.78150)$ and $\mathrm{Fe}(\mathrm{P}=0.44540)$ did not differ statistically. Thus, amniocentesis is an important diagnostic and exploratory tool in determining differences in the concentrations of elements such as heavy metal ions. Research over a longer period of time should be carried out to examine the relation between heavy metal ions concentration and possible postnatal health outcomes.

\section{Introduction}

The growth and development of the fetus is a complex phenomenon that can be influenced by several variables. Although electrolytes are present in the amniotic fluid in trace amounts, they are considered essential for the health and well-being of the fetus. Associations between amniotic fluid electrolyte concentrations and fetal development have been made (1). Common ions found in amniotic fluid include sodium, potassium, chloride, calcium, magnesium, phosphate and bicarbonate (2). These ions in the amniotic fluid serve an important role in a normal pregnancy and can aid in prevention and early diagnosis of fetal or maternal pathologies. Through accurate prenatal assessment of the biochemical composition of the amniotic fluid, overall health status and fetal maturity can be evaluated (1-3).

Normally, the volume of amniotic fluid increases steadily until it reaches a maximum of 400-1200 $\mathrm{ml}$ at 34-38 weeks. Afterwards, the volume starts to decline. At 40 weeks, the volume of amniotic fluid can measure $\sim 800 \mathrm{ml}$ and continues to decrease as the pregnancy goes on (4-6). Although the composition of the amniotic fluid does not remain constant during 
pregnancy, the bulk volume at all times $(\sim 98 \%)$ is water. Other important constituents are urea, creatinine, glucose, proteins, lipids, bile pigments, fetal epithelial cells and mineral ions (7).

Common ions have important uses during pregnancy. Sodium contributes to the regulation of water-electrolyte balance of the amniotic fluid, high chloride reflects possible renal pathologies, high potassium and calcium can be signs of pre-eclampsia, high phosphate indicates reduced antibacterial activity, magnesium and zinc $(\mathrm{Zn})$ assess the risk of fetal growth retardation (8-12). Potassium, phosphate and $\mathrm{Zn}$ also affect normal antimicrobial activity (13-15).

Some heavy metal ions can also be traced in the amniotic fluid, and small amounts of these elements are normal. However, large quantities have been shown to have detrimental effects in humans. For example, lead $(\mathrm{Pb})$ is known for its negative effects on neural development (16), while cadmium (Cd) is known for its risk of preterm delivery (17). Usually, this can be seen in people living in highly industrialized, highly polluted and poor areas (18-22). As such, the assessment of these ions in the amniotic fluid is essential to understanding the risks these people might be facing. Heavy metals in high concentrations have the ability to disrupt normal physiological processes. Copper $(\mathrm{Cu})$, arsenic (As), Cd, nickel (Ni), chromium, mercury, manganese and $\mathrm{Pb}$ can lead to fetal growth retardation, pre-eclampsia, impaired cognitive development and even cancer (23-28).

The present study had two objectives. The first was to assess the differences of heavy metal ion concentrations in the amniotic fluid between preterm (between weeks 15 and 37) and term (starting week 37) pregnancies. Moreover, the second was to assess whether pregnant women from two cities with different industrial levels from Romania would present different heavy metal ion concentrations in their amniotic fluid.

\section{Materials and methods}

Study design. The present retrospective study was conducted in the 'Bega' Maternity Clinic in Timisoara, Romania between April 1st 2020 and April 1st 2021. The study design is in accordance with The Declaration of Helsinki and was approved by the Ethics Committees of the 'Bega' Maternity Clinic (approval no. 260/16IUL2021) and Petrosani Hospital (approval no. 15990/27.07.2021).

Two cohorts of pregnant patients were examined. The first included 100 pregnant women admitted in the 'Bega' Maternity Clinic from Timisoara. The second included 60 pregnant women admitted in the Maternity Clinic of the Petrosani Emergency Hospital. Written informed consent was provided by all 160 individuals for amniocentesis and use of data for research purposes. Amniocentesis was performed on all patients, and each patient cohort was separated in two equal groups.

Participants. The inclusion criteria were as follows: Consenting adult women with single fetal gestation, patients with medical indications for amniocentesis (such as maternal age over 35, unfavorable or uncertain results obtained at screening tests, previous exposure to infectious agents including Toxoplasma gondii or cytomegalovirus and known genetic disorders running in the family). The exclusion criteria were: Pregnancies earlier than 15 weeks, pregnant patients with severe anemia, hematological, neoplastic, cardiac or metabolic conditions and patients with previous perinatal complications or fetal disorders.

Petrosani and Timisoara were selected in order to determine whether a mountainous, highly industrial city might harbor higher heavy metal ion concentrations in the amniotic fluid than a city in the plains, with moderate industry. The patients were stratified into four groups: Group $1(n=50)$, women from Timisoara with preterm pregnancies (15-37 weeks); group $2(\mathrm{n}=50)$, women from Timisoara with term pregnancies $(\geq 37$ weeks); group $3(n=30)$, women from Petrosani with preterm pregnancies; and group $4(n=30)$, women from Petrosani with term pregnancies.

Amniotic liquid sampling. All procedures were performed under careful sterile and antiseptic conditions. Before the amniocentesis procedure, an ultrasound evaluation was carried out in order to determine the location of the placenta, fetus and other characteristics of the amniotic fluid.

To enter the amniotic cavity, a spinal needle with a gauge of 20-22 was used under continuous ultrasound guidance. The entry into the amniotic cavity was done firmly in order to prevent rupture of the amniotic membrane and avoiding the placenta. Once the entry into the cavity was confirmed by ultrasound, the amniotic fluid was slowly aspirated. The first $2 \mathrm{ml}$ were discarded, as they may be contaminated with maternal cells. A quantity of 20-22 ml was deemed sufficient, as $18-20 \mathrm{ml}$ were used for genetic, sex and lung development testing (for pregnancies after week 32). The remaining $2 \mathrm{ml}$ were used for the evaluation of heavy metal ion concentration.

After removal of the needle, the mothers were kept under further ultrasound evaluation to confirm proper fetal heart rate. Intramuscular administration of anti-D immuno-globulin was also done for Rhesus-negative women in order to prevent fetal Rhesus disease. After completing the procedure, the mothers were advised to avoid strenuous and sexual activities for the next $48 \mathrm{~h}$.

Detection of heavy metal ions. The working method used for the detection of heavy metals in the amniotic fluid involved flame atomic absorption spectroscopy. Each amniotic fluid sample was nebulized in the gases of the spectrophotometer's flame. Each of the studied metals have well-known specific absorption rates and the spectrophotometer was also equipped with an interference correction system. All measurements are presented in $\mathrm{mg} / \mathrm{l}$.

The method follows national guidelines (SR ISO $8288 / 2001$ standards). All reagents used in this determination were of high quality and the water used was ultrapure, with no traces of heavy metals. All spectrophotometer readings were analyzed on a connected computer running GBC Avanta 1.33 (GBC Scientific Equipment). The calibration values used for the readings are presented in Table $\mathrm{I}$.

Data collection. The following clinical and demographical data were collected for each patient: Age of the patient, gestational age, concentrations of $\mathrm{Pb}, \mathrm{Cu}, \mathrm{Ni}, \mathrm{Cd}, \mathrm{As}, \mathrm{Zn}$, iron ( $\mathrm{Fe}$ ) (in $\mathrm{mg} / \mathrm{l}$ ), femur length (in $\mathrm{mm}$ ), location of residence (urban or 
Table I. Calibration values for the flame atomic absorption spectroscopy.

\begin{tabular}{lccccccr}
\hline Metal & $\mathrm{Zn}$ & $\mathrm{Cu}$ & $\mathrm{Cd}$ & $\mathrm{Ni}$ & $\mathrm{Pb}$ & $\mathrm{As}$ & $\mathrm{Fe}$ \\
\hline Maximum error & 0.037 & 0.027 & 0.012 & 0.039 & 0.083 & 0.027 & 0.013 \\
$\mathrm{R}^{2}$ & 0.999 & 1.000 & 0.999 & 0.998 & 0.995 & 0.998 & 1.000 \\
\hline
\end{tabular}

$\mathrm{Zn}$, zinc; $\mathrm{Cu}$, copper; $\mathrm{Cd}$, cadmium; Ni, nickel; $\mathrm{Pb}$, lead; As, arsenic; $\mathrm{Fe}$, iron.

rural) and smoking status (no smoking, either smoking in the past or quitting the habit once the patient found out about the pregnancy and active smoking). The data were recorded in an Excel file (2016 Office Suite, Microsoft).

Smoker status. Information on tobacco use was also collected. Active smokers were defined as patients smoking even during pregnancy. Former smokers were defined as patients that had smoked and gave up the habit in the past, as well as mothers, which quit smoking once the pregnancy was suspected and/or confirmed. Nonsmokers were defined as patients that never smoked.

Statistical analysis. Normal distribution was assessed using the Shapiro-Wilk test. Descriptive statistics for numerical variables include means, standard deviations, medians, interquartile range (IQR, 1st quartile - 3rd quartile) and range. For the comparison of with non-parametric variables, the Mann-Whitney U test was used. For categorical variables, frequency (\%) and/or count (n) were included, and Fisher's exact test used to analyze the contingency tables. The $\alpha$-level was set at 0.05 . $\mathrm{P}<005$ was considered to indicate a statistically significant difference. All data were processed using SPSS version 22 for Windows (IBM Corp.).

\section{Results}

Overview. In the Timisoara cohort, a total of 100 pregnant women between the age of 20 and 35 were admitted in the maternity during the study period. The mean maternal ages for groups 1 (preterm) and 2 (term) were 27.76 \pm 3.83 and 2 $7.46 \pm 3.58$ years, respectively. Mean gestational age was $18.14 \pm 1.81$ weeks for the preterm group and $38.66 \pm 1.04$ weeks for the term group. Mean femur length for the preterm group was $24.94 \pm 6.32$ and $74.55 \pm 2.65$ for the term group. All demographic data are presented in Table II. The distribution of the area of residence distribution is presented in Fig. 1. Statistical analysis of the area of residence did not reveal a significant difference between the groups $(\mathrm{P}=0.83694$; Fisher's exact test).

The Petrosani cohort consisted of 60 pregnant women between the age of 19 and 35 admitted in the maternity. The mean maternal age was $27.20 \pm 4.47$ years for group 3 (preterm) and 26.47 \pm 4.09 years for group 4 (term). Mean gestational age was $18.33 \pm 1.84$ weeks for the preterm group and 39.07 \pm 0.94 weeks for the term group. Mean femur length for the preterm group was $25.15 \pm 5.98$ and $76.13 \pm 1.76$ for the term group. The demographic data for these groups are presented in Table III. The distribution of the area of residence
Table II. Demographic data for patients from Timisoara.

\begin{tabular}{lcc}
\hline Parameter & $\begin{array}{c}\text { Preterm } \\
\text { pregnancies }\end{array}$ & $\begin{array}{c}\text { Term } \\
\text { pregnancies }\end{array}$ \\
\hline Gestational age, weeks & & \\
Mean & 18.14 & 38.66 \\
SD & 1.81 & 1.04 \\
Median & 18.00 & 39.00 \\
IQR & $16.88-19.88$ & $38.00-39.00$ \\
Range & 6.00 & 4.00 \\
Maternal age, years & & \\
Mean & 27.76 & 27.46 \\
SD & 3.83 & 3.58 \\
Median & 28.00 & 28.00 \\
IQR & $24.88-30.13$ & $26.00-29.00$ \\
Range & 15.00 & 15.00 \\
FL, mm & & \\
Mean & 24.94 & 74.55 \\
SD & 6.32 & 2.65 \\
Median & 25.30 & 75.05 \\
IQR & $19.80-29.44$ & $72.39-75.63$ \\
Range & 23.50 & 11.70 \\
\hline
\end{tabular}

FL, femur length; IQR, interquartile range; SD, standard deviation.

distribution is presented in Fig. 2. Statistical analysis of the area of residence using Fisher's exact test showed no significant difference between the groups $(\mathrm{P}=0.42956)$.

Analysis of the Timisoara cohort. In the Timisoara cohort, there were no statistically significant differences in the heavy metal ion concentrations between pre-term and term pregnancies (Table IV).

Analysis of the Petrosani cohort. In the Petrosani cohort, no statistically significant differences were observed between pre-term and term pregnancies regarding $\mathrm{Pb}, \mathrm{Cu}, \mathrm{Ni}, \mathrm{As}$ and $\mathrm{Fe}$ concentrations. However, the concentrations of $\mathrm{Cd}$ and $\mathrm{Zn}$ were significantly higher in the pre-term than in the term pregnancies (Table V).

Analysis between Timisoara and Petrosani. The Timisoara and Petrosani were also analyzed as a whole. No significant differences were observed with respect to $\mathrm{Ni}$ and $\mathrm{Fe}$ concentrations. However, the median concentrations of $\mathrm{Pb}, \mathrm{Cd}$, As and 
A

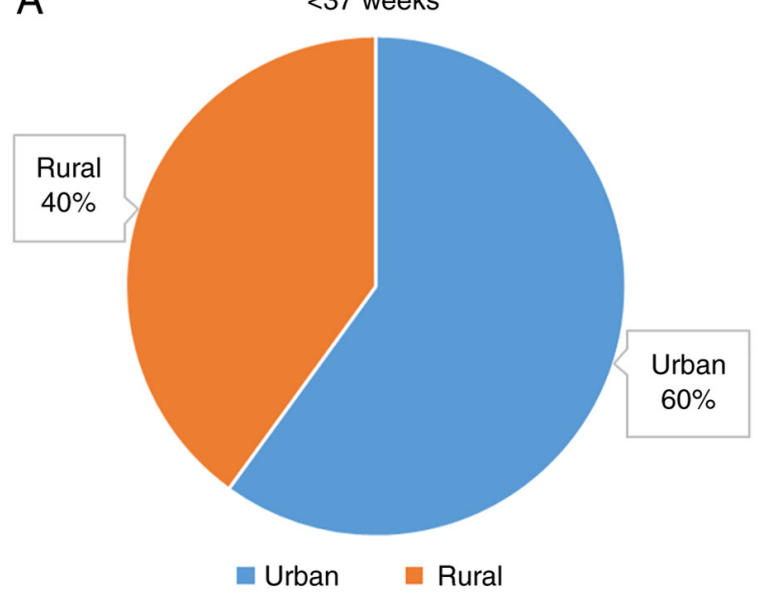

B

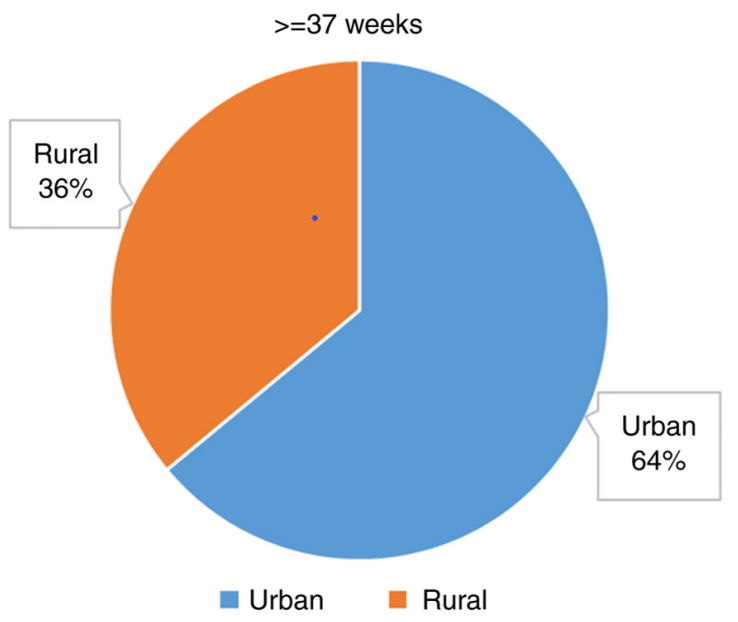

Figure 1. Area of residence of patients from Timisoara with (A) preterm and (B) term pregnancies.

A

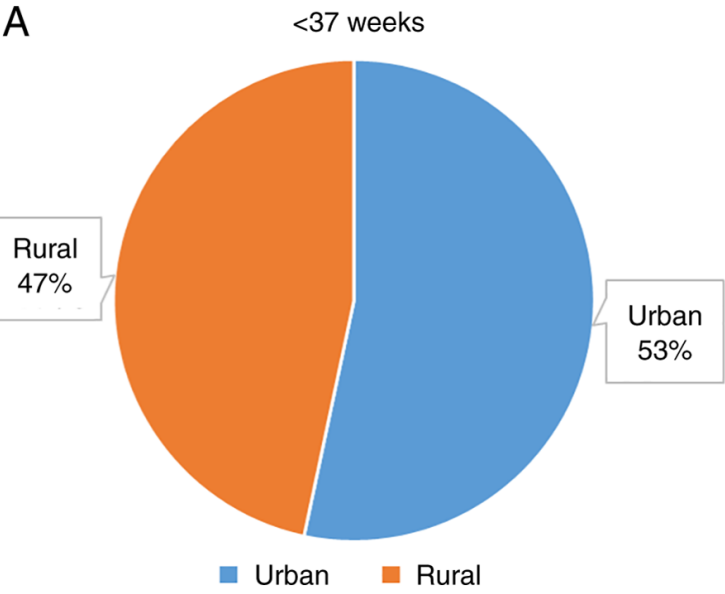

B

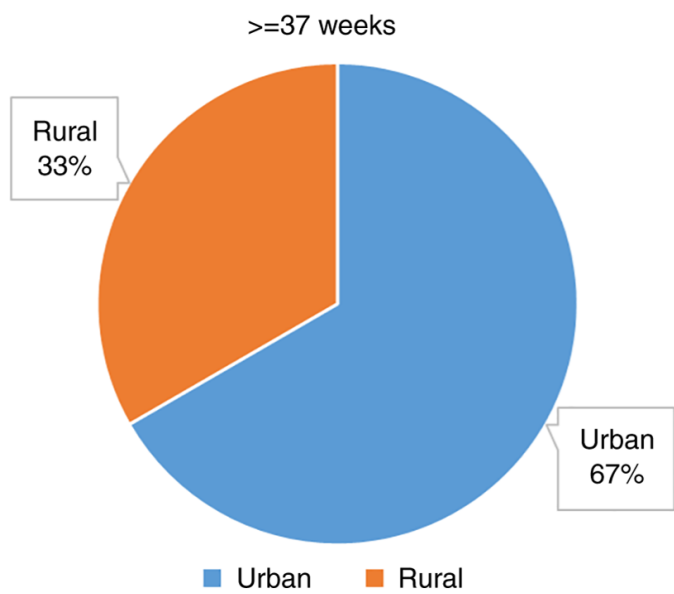

Figure 2. Area of residence of patients from Petrosani with (A) preterm and (B) term pregnancies.

A

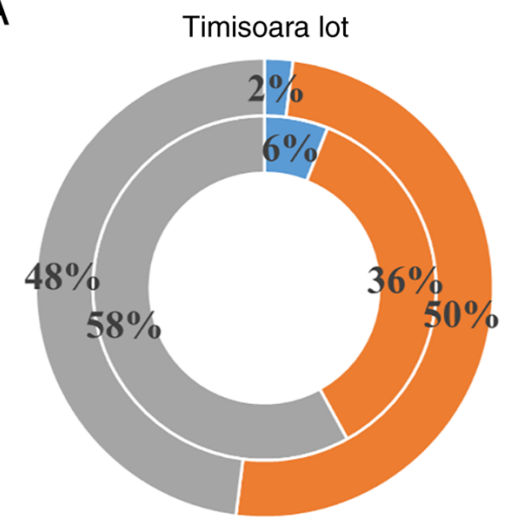

- Active smoker

Former smoker

- Non-smoker

$\mathrm{B}$

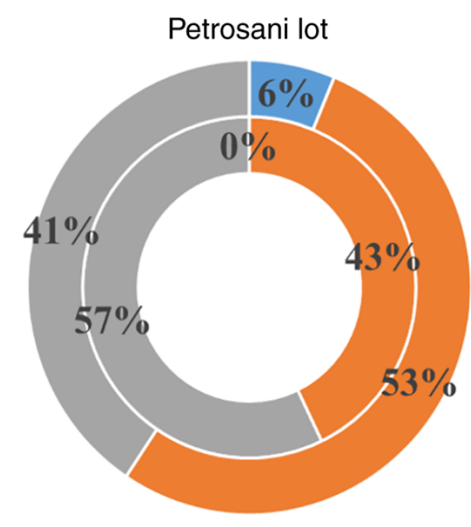

- Active smoker

- Former smoker

Figure 3. Smoking status of patients from (A) Timisoara and (B) Petrosani. The inner circle represents preterm pregnancies ( $<37$ weeks), while the outer circle represents term pregnancies ( $\geq 37$ weeks).

Zn were significantly higher in the Petrosani cohort, compared with patients from Timisoara. The median $\mathrm{Cu}$ concentration was significantly higher in the Timisoara cohort, compared with that in the Petrosani cohort (Table VI).
Analysis of smoking status. As smoking may affect the concentrations of trace elements such as heavy metal ions in the blood, urine, hair and toenail samples, the smoking status of the patients was also assessed. Fisher's exact test was used 
Table III. Demographic data for patients from Petrosani.

\begin{tabular}{lcc}
\hline Parameter & $\begin{array}{c}\text { Preterm } \\
\text { pregnancies }\end{array}$ & $\begin{array}{c}\text { Term } \\
\text { pregnancies }\end{array}$ \\
\hline Gestational age, weeks & & \\
Mean & 18.33 & 39.07 \\
SD & 1.84 & 0.94 \\
Median & 18.00 & 39.00 \\
IQR & $17.00-20.00$ & $38.00-39.88$ \\
Range & 6.00 & 3.00 \\
Maternal age, years & & \\
Mean & 27.20 & 26.47 \\
SD & 4.47 & 4.09 \\
Median & 28.00 & 26.50 \\
IQR & $23.75-30.13$ & $23.88-29.00$ \\
Range & 16.00 & 15.00 \\
FL, mm & & \\
Mean & 25.15 & 76.13 \\
SD & 5.98 & 1.76 \\
Median & 25.35 & 75.50 \\
IQR & $19.41-30.24$ & $75.49-77.10$ \\
Range & 22.30 & 7.90 \\
\hline
\end{tabular}

FL, femur length; IQR, interquartile range; SD, standard deviation.

to see if the smoking status was associated with gestational age or with the area of residence. (Table VII; Figs. 3 and 4). There was no association between smoking status and either of these two parameters.

\section{Discussion}

Amniotic fluid plays a key role in the development of the fetus. It protects the fetus from mechanical shock and insulates it thermally, whilst helping elements from the maternal plasma reach the fetus, especially in the early pregnancy, before the formation of the placenta and it participates in keeping the antibacterial balance. These properties are the result of the bioactive compounds that take part in its constitution (7).

Since implantation, the extracolemic cavity is produced, forming the amniotic space. The fetus and the amniotic fluid are enveloped by the amniotic sac. At weeks 34-38 the amniotic fluid reaches its maximum value, after which it starts declining as the pregnancy goes on (4-6). However, the concentrations of its bioactive compounds changes as the osmolarity of the fluid decreases. These concentrations are important as they can provide insight into the status of the fetus through amniocentesis.

Although they are found in small amounts, mineral ions can play an important role in the development of the fetus. Common ions are sodium, chloride, potassium, calcium, magnesium, bicarbonate and phosphate $(2,7,29)$. In addition, trace levels of heavy metals, such as $\mathrm{Cu}$, As, $\mathrm{Cd}$, Ni, chromium, mercury, manganese, $\mathrm{Zn}$ and $\mathrm{Pb}$, can also be found in the amniotic fluid $(1,2,7)$.

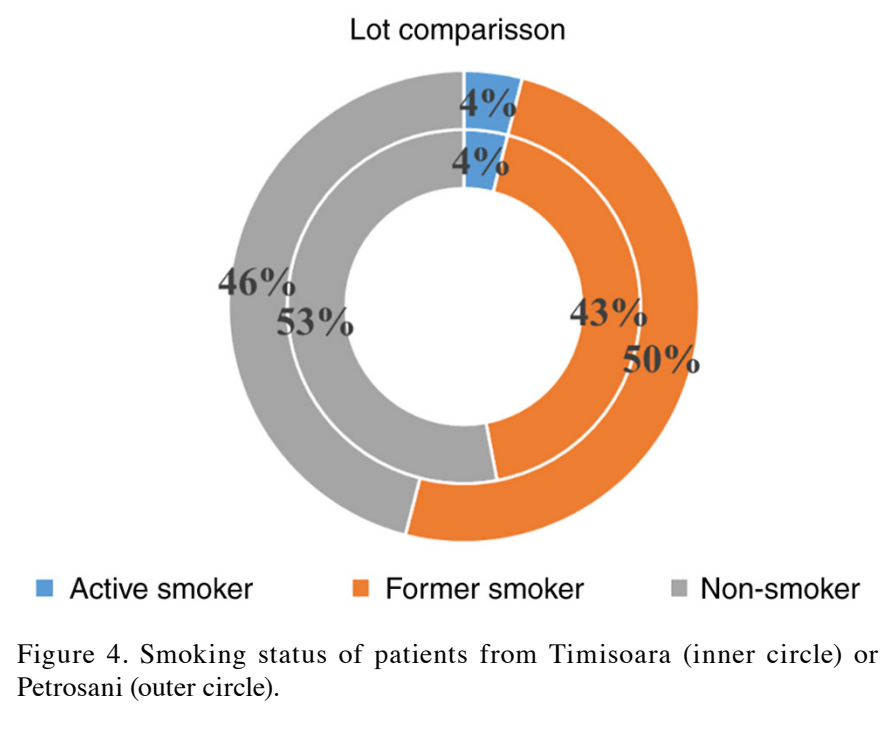

Sodium is involved in regulating the water-electrolyte balance (9,29-31). Chloride can be used to determine possible renal disorders, such as the Barter syndrome $(8,9,32)$. Raised potassium levels may lead to pre-eclampsia and lower antibacterial activity $(11,14)$. Elevated calcium levels can result in pre-eclampsia and spina bifida, while low levels are associated with preterm deliveries (33-37). Low levels of magnesium have been associated with pre-eclampsia and possible fetal growth retardation $(12,13,38-40)$. High bicarbonate may indicate complicated twin-twin transfusion syndromes (41), while phosphate plays a role in antimicrobial activity (42-44).

Heavy metals are metalloids with high density or atomic number, which are usually found in trace amounts in serum. Several have well-known physiological functions, such as heme constitution, hormone production, enzyme regulation or even act as antioxidants (45). Therefore, it is normal for these elements to be found in tissues and bodily fluids. When concentrations are elevated however, certain health risks may appear. In adults, risks range from acute hepatic injury, cardiovascular, neuro-psychological disorders to chronic poisoning or even death (46-48). Considering the risks adults are exposed to, prudence is advisable regarding the risks in children.

$\mathrm{Zn}$ is essential for embryogenesis and neurogenesis. Deficiency in this element is associated with fetal growth retardation and neurodegenerative disorders $(28,49-51)$. It may also promote antimicrobial activity $(15,17)$. Due to these concerns, similarly to magnesium and iron, supplementation for both pregnant and lactating mothers is recommended. The average intake is in the range of $9.6-11.2 \mathrm{mg} / \mathrm{day}(51,52)$. Another reason to determine the amniotic fluid levels is that oxidative stress, induced by menadione, is further exacerbated by high concentrations $(80 \mu \mathrm{M})$ of $\mathrm{Zn}$ (53). In the Timisoara cohort of the present study, the differences in $\mathrm{Zn}$ concentrations between term and preterm pregnancies were not statistically significant. In the Petrosani cohort, the preterm pregnancy group had a median $\mathrm{Zn}$ concentration higher than that of the term pregnancy group. The differences between the two cohort were also statistically significant.

$\mathrm{Cu}$ is an essential cofactor for several metalloenzymes. It also has antimicrobial and antiviral properties. Average intake varies from 0.6 to $1.6 \mathrm{mg} / \mathrm{day}$, although this can be higher 
Table IV. Heavy metal concentrations in patients from Timisoara $(n=100)$ with preterm and term pregnancies.

\begin{tabular}{|c|c|c|c|c|c|c|}
\hline Metal & Mean & SD & Median & IQR & Range & P-value ${ }^{a}$ \\
\hline \multicolumn{7}{|l|}{$\mathrm{Pb}$} \\
\hline Preterm & 0.0409 & 0.1582 & 0.0001 & $0.0000-0.0136$ & 1.012 & \multirow[t]{2}{*}{0.74300} \\
\hline Term & 0.0570 & 0.1944 & 0.0002 & $0.0000-0.0138$ & 1.012 & \\
\hline \multicolumn{7}{|l|}{$\mathrm{Cu}$} \\
\hline Preterm & 0.4736 & 0.5068 & 0.2840 & $0.0829-0.9263$ & 1.662 & \multirow[t]{2}{*}{0.59780} \\
\hline Term & 0.5810 & 0.5106 & 0.3690 & $0.0780-1.0339$ & 1.738 & \\
\hline \multicolumn{7}{|l|}{$\mathrm{Ni}$} \\
\hline Preterm & 0.4426 & 0.6478 & 0.0131 & $0.0000-0.9954$ & 2.057 & \multirow[t]{2}{*}{0.09952} \\
\hline Term & 0.6863 & 0.7292 & 0.7175 & $0.0000-1.2206$ & 2.787 & \\
\hline \multicolumn{7}{|l|}{$\mathrm{Cd}$} \\
\hline Preterm & 0.0067 & 0.0354 & 0.0001 & $0.0000-0.0001$ & 0.238 & \multirow[t]{2}{*}{0.69680} \\
\hline Term & 0.0103 & 0.0429 & 0.0001 & $0.0000-0.0001$ & 0.240 & \\
\hline \multicolumn{7}{|l|}{ As } \\
\hline Preterm & 0.9131 & 1.0294 & 0.5530 & $0.0000-1.7294$ & 3.769 & \multirow[t]{2}{*}{0.17080} \\
\hline Term & 0.7219 & 0.9954 & 0.0020 & $0.0000-1.4208$ & 3.767 & \\
\hline \multicolumn{7}{|l|}{$\mathrm{Zn}$} \\
\hline Preterm & 0.0776 & 0.1518 & 0.0145 & $0.0000-0.0674$ & 0.658 & \multirow[t]{2}{*}{0.98310} \\
\hline Term & 0.0534 & 0.1329 & 0.0140 & $0.0000-0.0369$ & 0.742 & \\
\hline \multicolumn{7}{|l|}{$\mathrm{Fe}$} \\
\hline Preterm & 0.3072 & 0.3624 & 0.1504 & $0.0414-0.4477$ & 1.500 & \multirow[t]{2}{*}{0.13470} \\
\hline Term & 0.3332 & 0.3126 & 0.2333 & $0.1769-0.3369$ & 1.382 & \\
\hline
\end{tabular}

${ }^{a}$ Mann Whitney's U-test. IQR, interquartile range; SD, standard deviation.

during pregnancy and breastfeeding (54). Deficits may lead to neurological and immunological abnormalities of the fetus (54). By contrast, high $\mathrm{Cu}$ concentrations may lead to diverse abnormalities. For example, high concentrations in maternal serum have been linked to pre-eclampsia $(55,56)$, and elevated levels in the amniotic fluid have been associated with fetal growth retardation (28). When considering genetics, $\mathrm{Cu}$ is has been implicated in two major diseases, namely Wilson and Menkes diseases. In both cases, accumulation of $\mathrm{Cu}$ in the fetus can usually be observed prenatally (57-60). In the present study, the differences between term and preterm pregnancies were not statistically significant, both for patients from Timisoara and from Petrosani. When comparing the two cohorts, the Timisoara cohort presented higher median concentrations, with the differences being statistically significant.

$\mathrm{Ni}$ is essential for gut bacterial growth, hormone production, iron absorption and as part of RNA and DNA. Recommended dietary allowance for women is 400-600 $\mu \mathrm{g} /$ day $(61,62)$. Large doses of $\mathrm{Ni}$ or prolonged exposure can cause harmful effects such as genotoxicity, hematotoxicity, teratogenicity, immunotoxicity, carcinogenicity and allergic reactions $(62,63)$. Smokers and families with lower socio-economic status might be exposed to higher doses (62-64). Rodent models have shown that the transfer of Ni through the placenta occurs mainly from the mother to the fetus, resulting in its accumulation in the amniotic fluid or fetal organs $(65,66)$. In the present study, the differences between term and preterm pregnancies were not considered statistically significant for both cohorts. There were no statistically significant differences in Ni concentrations between the two cohorts.

$\mathrm{Fe}$ is an important molecule that serves several functions in the body, with the most important role being in oxygen transportation, as part of the heme structure (67). Another important role is combating infections (68). Normal intake for iron is $16 \mathrm{mg} /$ day for women and $7-11 \mathrm{mg} /$ day for children $<14$ years (69). Fe deficiency is a common worldwide problem leading to anemia. Children and pregnant women are at a high risk for this condition and may need supplementation. During pregnancy, total intake should reach $27 \mathrm{mg} /$ day, while during lactation, the recommended intake falls to $10 \mathrm{mg} /$ day (70).

Deficiency and anemia in pregnant women has been associated with low birth weight, preterm delivery and potential fetal anemia (71,72). During intra-amniotic infection or inflammation complications, the amniotic levels of Fe are not significantly increased compared with healthy individuals. This may be due to hepcidin upregulation, which may result in hypoferremia in maternal serum, as hepcidin redirects $\mathrm{Fe}$ to macrophages correlated with the infection or inflammation episode $(73,74)$. Common symptoms of Fe deficiency anemia include paleness, fatigue, reduced cognitive performance and diminished immune responses. Infants experience these as well, along with an increased risk of cognitive and psychomotor developmental deficit (75).

Excess Fe can be observed after repeated blood transfusions or in congenital cases of hemochromatosis. Mutations 
Table V. Heavy metal concentrations in patients from Petrosani $(n=60)$ with preterm and term pregnancies.

\begin{tabular}{|c|c|c|c|c|c|c|}
\hline Metal & Mean & $\mathrm{SD}$ & Median & IQR & Range & P-value ${ }^{a}$ \\
\hline \multicolumn{7}{|l|}{$\mathrm{Pb}$} \\
\hline Preterm & 0.0728 & 0.2249 & 0.0020 & $0.0000-0.0284$ & 1.124 & \multirow[t]{2}{*}{0.20840} \\
\hline Term & 0.1579 & 0.3048 & 0.0190 & $0.0000-0.0865$ & 1.202 & \\
\hline \multicolumn{7}{|l|}{$\mathrm{Cu}$} \\
\hline Preterm & 0.0386 & 0.0519 & 0.0265 & $0.0054-0.0468$ & 0.265 & \multirow[t]{2}{*}{0.78420} \\
\hline Term & 0.0260 & 0.0200 & 0.0185 & 0.0109-0.0409 & 0.074 & \\
\hline \multicolumn{7}{|l|}{$\mathrm{Ni}$} \\
\hline Preterm & 0.5743 & 0.7706 & 0.0990 & $0.0000-1.2199$ & 2.198 & \multirow[t]{2}{*}{0.47120} \\
\hline Term & 0.7173 & 0.8653 & 0.1765 & $0.0000-1.4485$ & 2.898 & \\
\hline \multicolumn{7}{|l|}{$\mathrm{Cd}$} \\
\hline Preterm & 0.0135 & 0.0463 & 0.0003 & $0.0000-0.0020$ & 0.235 & \multirow[t]{2}{*}{$0.01512^{\mathrm{b}}$} \\
\hline Term & 0.0070 & 0.0368 & 0.0001 & $0.0000-0.0001$ & 0.202 & \\
\hline \multicolumn{7}{|l|}{ As } \\
\hline Preterm & 1.0785 & 0.9899 & 0.7525 & $0.2260-1.7548$ & 3.004 & \multirow[t]{2}{*}{0.66710} \\
\hline Term & 1.1075 & 1.2392 & 0.7632 & $0.0086-1.8127$ & 4.743 & \\
\hline \multicolumn{7}{|l|}{$\mathrm{Zn}$} \\
\hline Preterm & 0.2202 & 0.2975 & 0.0845 & $0.0344-0.3295$ & 1.259 & \multirow[t]{2}{*}{$0.02606^{\mathrm{b}}$} \\
\hline Term & 0.0604 & 0.053 & 0.0425 & 0.0199-0.0989 & 0.177 & \\
\hline \multicolumn{7}{|l|}{$\mathrm{Fe}$} \\
\hline Preterm & 0.3377 & 0.4297 & 0.1235 & $0.0704-0.5135$ & 1.747 & \multirow[t]{2}{*}{0.16690} \\
\hline Term & 0.4119 & 0.3316 & 0.3760 & $0.1406-0.6029$ & 1.500 & \\
\hline
\end{tabular}

${ }^{a}$ Mann Whitney's U-test, ${ }^{\text {b}}$ statistically significant. IQR, interquartile range; SD, standard deviation.

of the High $\mathrm{Fe}^{2+}$ protein family and other $\mathrm{Fe}$ transport proteins lead to iron build-up in the organism, resulting in liver cirrhosis, hepatocellular carcinoma, heart disease and impaired pancreatic function (76). Although these symptoms usually appear in later life, infants with Fe overload may be at risk of developing brain and hematopoiesis alterations (77).

In the present study, the differences in Fe concentrations between term and preterm pregnancies were not considered statistically significant in the Timisoara or Petrosani cohorts. Nor were there any differences between the two cohorts.

$\mathrm{Cd}$ is an element still being investigated, along with $\mathrm{Pb}$ and As. It is commonly found in cigarettes. Present only in very small amounts in the body, no physiological role has been established yet. As a toxic element, previous studies have looked into its effects on cardiovascular function $(78,79)$, obesity and ghrelin regulation $(80,81)$, possible cancer occurrence $(82,83)$, reproduction and pregnancy $(84-87)$. Rodent fetal experimentation has suggested cytotoxicity problems, progesterone disorders, microRNA expression changes, elevated oxidative stress and DNA damage (84-86). The toxic effects from $\mathrm{Cd}$, such as high oxidative stress, cytotoxicity and apoptosis have also been shown in humans (87). Prenatal exposure has been linked with lower birth weights, preterm deliveries and even possible spontaneous abortion (88-90). Elevated amniotic fluid levels have been also linked with pre-eclampsia $(26,91)$. Children with such prenatal history might also be prone to cardiometabolic disorders (92). In the present study, the differences in $\mathrm{Cd}$ concentration between term and preterm pregnancies were not considered statistically significant in patients from Timisoara. In the Petrosani cohort, the median concentrations for the preterm pregnancy group were significantly higher, compared with the term group. Compared with patients from Timisoara, the Petrosani cohort presented significantly higher median concentrations.

As is an element known since ancient times, where it was frequently used as a poison. Very small amounts do have some physiological functions, interacting with the metabolism of selenium and methionine; the normal dose is in the range of 12-40 $\mu \mathrm{g} /$ day $(93,94)$. Except for the derivative arsenic trioxide $\left(\mathrm{As}_{2} \mathrm{O}_{3}\right)$, which has antitumor properties, the levels of As should be maintained in the recommended levels, as high doses can lead to neuronal insulin signaling disruption and the development of malignancies, severe gastrointestinal toxicities, diabetes, cardiac arrhythmias or even death (95-97). Related neurological problems include lower IQ levels, attention-deficit/hyperactivity disorder and autism spectrum disorders $(98,99)$. Elevated maternal levels have been associated with maternal hypertension preterm deliveries, low birth weight and even possible spontaneous abortion $(23,24,100,101)$. In the present study, the differences between term and preterm pregnancies were not considered 
Table VI. Comparison of heavy metal concentrations in the amniotic fluid between the Timisoara $(n=100)$ and the Petrosani $(n=60)$ groups.

\begin{tabular}{|c|c|c|c|c|c|c|}
\hline Metal & Mean & SD & Median & IQR & Range & P-value \\
\hline \multicolumn{7}{|l|}{$\mathrm{Pb}$} \\
\hline Timisoara & 0.0489 & 0.1765 & 0.0001 & $0.0000-0.0130$ & 1.012 & \multirow[t]{2}{*}{$0.04513^{\mathrm{b}}$} \\
\hline Petrosani & 0.1136 & 0.2671 & 0.0030 & $0.0000-0.0468$ & 1.202 & \\
\hline \multicolumn{7}{|l|}{$\mathrm{Cu}$} \\
\hline Timisoara & 0.5281 & 0.5339 & 0.3225 & $0.0805-1.0230$ & 1.738 & \multirow[t]{2}{*}{$<0.00001^{\mathrm{b}}$} \\
\hline Petrosani & 0.0322 & 0.0392 & 0.0190 & $0.0090-0.0433$ & 0.265 & \\
\hline \multicolumn{7}{|l|}{$\mathrm{Ni}$} \\
\hline Timisoara & 0.5645 & 0.6970 & 0.0010 & $0.0000-1.1390$ & 2.787 & \multirow[t]{2}{*}{0.78150} \\
\hline Petrosani & 0.6480 & 0.8089 & 0.0504 & $0.0000-1.3100$ & 2.898 & \\
\hline \multicolumn{7}{|l|}{$\mathrm{Cd}$} \\
\hline Timisoara & 0.0085 & 0.0392 & 0.0001 & $0.0000-0.0001$ & 0.239 & \multirow[t]{2}{*}{$0.00002^{\mathrm{b}}$} \\
\hline Petrosani & 0.0101 & 0.0413 & 0.0001 & $0.0000-0.0010$ & 0.235 & \\
\hline \multicolumn{7}{|l|}{ As } \\
\hline Timisoara & 0.8175 & 1.0120 & 0.2310 & $0.0000-1.5270$ & 3.768 & \multirow[t]{2}{*}{$0.03027^{\mathrm{b}}$} \\
\hline Petrosani & 1.0751 & 1.1116 & 0.7400 & $0.0685-1.7029$ & 4.743 & \\
\hline \multicolumn{7}{|l|}{$\mathrm{Zn}$} \\
\hline Timisoara & 0.0664 & 0.1462 & 0.0140 & $0.0000-0.0560$ & 0.742 & \multirow[t]{2}{*}{$<0.00001^{\mathrm{b}}$} \\
\hline Petrosani & 0.1394 & 0.2249 & 0.0530 & $0.0238-0.1418$ & 1.266 & \\
\hline \multicolumn{7}{|l|}{$\mathrm{Fe}$} \\
\hline Timisoara & 0.3202 & 0.3370 & 0.2219 & $0.0982-0.4240$ & 1.500 & \multirow[t]{2}{*}{0.44540} \\
\hline Petrosani & 0.3735 & 0.3793 & 0.2660 & $0.0883-0.5653$ & 1.768 & \\
\hline
\end{tabular}

${ }^{a}$ Mann Whitney's U-test, ${ }^{\text {b }}$ statistically significant. IQR, interquartile range; SD, standard deviation.

Table VII. Smoking status of patients from the Timisoara and the Petrosani groups.

\begin{tabular}{|c|c|c|c|c|}
\hline Patient group & Active smoker, $\mathrm{n}$ & Former smoker, $\mathrm{n}$ & Non-smoker, $\mathrm{n}$ & P-value ${ }^{a}$ \\
\hline Timisoara (all patients) & 4 & 43 & 53 & 0.7193 \\
\hline Petrosani (all patients) & 2 & 28 & 30 & \\
\hline \multicolumn{5}{|l|}{ Timisoara } \\
\hline Preterm & 3 & 18 & 29 & 0.26855 \\
\hline Term & 1 & 25 & 24 & \\
\hline \multicolumn{5}{|l|}{ Petrosani } \\
\hline Preterm & 0 & 12 & 16 & 0.23577 \\
\hline Term & 2 & 17 & 13 & \\
\hline
\end{tabular}

${ }^{\mathrm{a}}$ Fisher's exact test.

statistically significant, both for patients from Timisoara and from Petrosani. When comparing the two cohorts, the Petrosani cohort presented significantly higher median concentrations of As.

$\mathrm{Pb}$ is well-known for its high toxicity and has no known physiological roles, and as such, avoiding contact with this metal is advised. $\mathrm{Pb}$ poisoning affects the kidneys, the cardiovascular system, reproduction and especially the neurological and psychologic systems, as it can pass the blood-brain barrier (102-106). In children, the neurological and psychological effects can be drastic, as their brains and mind undergo much development. This can lead to problems such as lower IQ levels, attention-deficit/hyperactivity disorder and antisocial disorders (107-109). Other pediatric disorders due to elevated lead concentrations in the mother's serum could be reduced glomerular filtration, asthma, immunological and dermatological disorders (110-113). Perinatal effects of high $\mathrm{Pb}$ concentrations are low birth 
weight, preterm delivery, pre-eclampsia and pregnancy hypertension $(90,114-117)$. Umbilical cord blood analysis has also shown that $\mathrm{Pb}$ affects DNA methylation and has also confirmed the reduced intellectual abilities of children coming from pregnancies with exposure to $\mathrm{Pb}(118,119)$. In the present study, the differences in $\mathrm{Pb}$ between term and preterm pregnancies were not statistically significant in either cohort. Compared with the Timisoara cohort, the patients from Petrosani presented significantly higher median concentrations of $\mathrm{Pb}$.

For both cohorts, the differences between the preterm and term pregnancies were minimal. Indeed, no statistically significant differences were observed in the Timisoara cohorts, and the patients from Petrosani only showed higher concentrations of $\mathrm{Zn}$ and $\mathrm{Cd}$ in the preterm pregnancy group. More importantly, the comparison between the two cities showed that patients from Petrosani, a well-known industrial region, had higher concentrations of $\mathrm{Zn}, \mathrm{Cd}, \mathrm{Pb}$ and As. This is in agreement with other international studies showing that people living in industrialized regions are susceptible to accumulation of these elements, even if they mostly measured the concentrations either in the mother's serum, urine, toe-nails, hair, fetal placenta and cord blood $(16-22,90,115,120,121)$. These elements are important as their concentration may be further increased by tobacco and are secreted in colostrum and breast milk (122). These elements are also some of the more toxic metalloids. Concern regarding their levels and possible health problems has also been expressed in other studies $(46,47,92,99,111,113,123)$.

The smoking status of mothers can influence concentrations in blood, urine, hair or toe-nail samples (124-127). However, in order to avoid this, the patients in the present study were separated in three groups. Active smokers were defined as patients smoking even during pregnancy. Former smokers were defined as patients that had smoked and gave up the habit in the past, as well as mothers, which quit smoking once the pregnancy was suspected and/or confirmed. Nonsmokers were defined as patients that never smoked. There was no association between smoking status and gestational age, nor with any of the two cities in particular. Therefore, smoking status may not be an interfering element with respect to the concentration of heavy metal ions.

There are some limitations to this study. Larger sample lots might help produce finer, more accurate results. The design of the study may result in unequal follow-up, as it involved two maternity clinics from different cities. All mothers were recommended supplements such as Elevit 2 (Bayer, Germany) or Femosun (Sun Wave Pharma, Ascendis Health, South Africa), which may interfere with some of the recorded elements, especially Fe. Another limitation, which was not analyzed, may be the frequency of smoking, represented by the number of cigarettes smoked by an individual per day. Only the smoker status was assessed under the labels previously described.

In conclusion, bioactive components found in the amniotic fluid are important and can be monitored through amniocentesis. This tool enables healthcare professionals to assess the condition of the developing fetus. Common ions have been largely studied in the past. Heavy metal ions require more attention as minimal differences in concentration might influence the fetal development. $\mathrm{Cd}$ and $\mathrm{Pb}$ are elements with high toxicity and almost no physiological function. Thus, the authors recommend that these elements be avoided, especially by pregnant women and children. Metalloids such as $\mathrm{Fe}, \mathrm{Cu}$, $\mathrm{Zn}$ or $\mathrm{Ni}$ are to be discussed by expecting mothers with their healthcare provider, in order to check if any supplementation is needed. More in-depth research should be done in order to outline the effects of these elements and to determine how they affect antenatal outcomes and childhood development in the long run.

\section{Acknowledgements}

Not applicable.

\section{Funding}

No funding was received.

\section{Availability of data and materials}

All data generated or analyzed during this study are included in this published article.

\section{Authors' contributions}

RIN, GD, AD and AM contributed substantially to the conception and design of the study, the acquisition, analysis and interpretation of the data, and were involved in the drafting of the manuscript. AVP, AGE, DDV, MC and ESB contributed substantially to the analysis and interpretation of the data and were involved in the drafting of the manuscript. IC, ICC, FGH and FG contributed substantially to the interpretation of the data and were involved in the critical revisions of the manuscript for important intellectual content. FGH, AM and $\mathrm{MC}$ are responsible for confirming the authenticity of all the raw data and supervision. All authors agreed to be accountable for all aspects of the work in ensuring that questions related to the accuracy or integrity of any part of the work are appropriately investigated and resolved. All authors read and approved the final version of the manuscript.

\section{Ethics approval and consent to participate}

This study design followed the international regulations in accordance with The Declaration of Helsinki. The study was approved by the Ethics Committees of the 'Bega' Maternity Clinic, (approval no. 260/16IUL2021) and Petrosani Hospital (approval no. 15990/27.07.2021). Patient informed consent for publication of the data associated with the manuscript was obtained.

\section{Patient consent for publication}

Not applicable.

\section{Competing interests}

The authors declare that they have no competing interests. 


\section{References}

1. Cassady G and Barnett R: Amniotic fluid electrolytes and perinatal outcome. Biol Neonat 13: 155-174, 1968.

2. Lind T, Billewicz WZ and Cheyne GA: Composition of amniotic fluid and maternal blood through pregnancy. J Obstet Gynaecol Br Commonw 78: 505-512, 1971.

3. Harman CR: Amniotic fluid abnormalities. Semin Perinatol 32: 288-294, 2008.

4. Brace RA and Wolf EJ: Normal amniotic fluid volume changes throughout pregnancy. Am J Obstet Gynecol 161: 382-388, 1989.

5. Elliott PM and Inman WH: Volume of liquor amnii in normal and abnormal pregnancy. Lancet 2: 835-840, 1961

6. Queenan JT, Thompson W, Whitfield CR and Shah SI: Amniotic fluid volumes in normal pregnancies. Am J Obstet Gynecol 114: 34-38, 1972.

7. Underwood MA, Gilbert WM and Sherman MP: Amniotic fluid: Not just fetal urine anymore. J Perinatol 25: 341-348, 2005.

8. Curran MA, Nijland MJ, Mann SE and Ross MG: Human amniotic fluid mathematical model: Determination and effect of intramembranous sodium flux. Am J Obstet Gynecol 178 : 484-490, 1998

9. Massa G, Proesmans W, Devlieger H, Vandenberghe K, Van Assche A and Eggermont E: Electrolyte composition of the amniotic fluid in Bartter syndrome. Eur J Obstet Gynecol Reprod Biol 24: 335-340, 1987

10. Fotiou M, Michaelidou AM, Masoura S, Menexes G, Koulourida V, Biliaderis CG, Tarlatzis BC and Athanasiadis AP: Second trimester amniotic fluid uric acid, potassium, and cysteine to methionine ratio levels as possible signs of early preeclampsia: A case report. Taiwan J Obstet Gynecol 55: 874-876, 2016.

11. Weiss M, Frenkel Y, Dolev E, Barkai G, Mashiach S and Sela BA: Increased amniotic fluid divalent cation concentrations in preeclampsia. J Basic Clin Physiol Pharmacol 6: 71-77, 1995.

12. Dawson EB, Evans DR and Nosovitch J: Third-trimester amniotic fluid metal levels associated with preeclampsia. Arch Environ Health 54: 412-415, 1999.

13. Honkonen E, Näntö V, Hyörä H, Vuorinen $K$ and Erkkola $R$ : Trace elements and antibacterial activity in amniotic fluid. Neonatology 50: 21-26, 1986.

14. Scane TM and Hawkins DF: Antibacterial activity in human amniotic fluid: Relationship to zinc and phosphate. Br J Obstet Gynaecol 91: 342-348, 1984 .

15. Shankar AH and Prasad AS: Zinc and immune function: The biological basis of altered resistance to infection. Am J Clin Nutr 68 (Suppl 2): 447S-463S, 1998.

16. Dawson EB, Evans DR, Harris WA and Van Hook JW: Amniotic fluid B12, calcium, and lead levels associated with neural tube defects. Am J Perinatol 16: 373-378, 1999.

17. Asefi Y, Gohari Mahmoudabad A, Habibian Sezavar A, Mirshahvaladi S, Abyadeh $M$ and Abyareh $M$ : Association between maternal cadmium exposure and preterm birth: A meta-analysis. Int J Environ Health Res 7: 1-10, 2020.

18. Xu L, Dai H, Skuza L and Wei S: Comprehensive exploration of heavy metal contamination and risk assessment at two common smelter sites. Chemosphere 285: 131350, 2021.

19. Ilechukwu I, Osuji LC, Okoli CP, Onyema MO and Ndukwe GI: Assessment of heavy metal pollution in soils and health risk consequences of human exposure within the vicinity of hot mix asphalt plants in Rivers State, Nigeria. Environ Monit Assess 193: 461, 2021

20. Alsubih M, El Morabet R, Khan RA, Khan NA, Ul Haq Khan M, Ahmed S, Qadir A and Changani F: Occurrence and health risk assessment of arsenic and heavy metals in groundwater of three industrial areas in Delhi, India. Environ Sci Pollut Res Int 28 63017-63031, 2021.

21. Wongsasuluk P, Chotpantarat S, Siriwong W and Robson M: Human biomarkers associated with low concentrations of arsenic $(\mathrm{As})$ and lead $(\mathrm{Pb})$ in groundwater in agricultural areas of Thailand. Sci Rep 11: 13896, 2021

22. Wang Y, Qian P, Li D, Chen $\mathrm{H}$ and Zhou X: Assessing risk to human health for heavy metal contamination from public point utility through ground dust: A case study in Nantong, China. Environ Sci Pollut Res Int 2021 (Epub ahead of print).

23. Llanos MN and Ronco AM: Fetal growth restriction is related to placental levels of cadmium, lead and arsenic but not with an-tioxidant activities. Reprod Toxicol 27: 88-92, 2009.

24. Smeester L, Martin EM, Cable P, Bodnar W, Boggess K, Vora NL and Fry RC: Toxic metals in amniotic fluid and altered gene expression in cell-free fetal RNA. Prenat Diagn 37: 1364-1366, 2017.
25. Bonithon-Kopp C, Huel G, Moreau T and Wendling R: Prenatal exposure to lead and cadmium and psychomotor development of the child at 6 years. Neurobehav Toxicol Teratol 8: 307-310, 1986

26. Ebrahim K and Ashtarinezhad A: The association of amniotic fluid cadmium levels with the risk of preeclampsia, prematurity and low birth weight. Iran J Neonatol 6: 1-6, 2015.

27. Lewis M, Worobey J, Ramsay DS and McCormack M: Prenatal exposure to heavy metals: Effect on childhood cognitive skills and health status. Pediatrics 89 (6 Pt 1): 1010-1015, 1992.

28. Pogorelova TN, Linde VA, Gunko VO and Selyutina SN: The imbalance of metal-containing proteins and free metal ions in the amniotic fluid during fetal growth. Biomed Khim 62: 69-72, 2016 (In Russian).

29. Campbell J, Wathen N, Macintosh M, Cass P, Chard T and Mainwaring Burton R: Biochemical composition of amniotic fluid and extraembryonic coelomic fluid in the first trimester of pregnancy. Br J Obstet Gynaecol 99: 563-565, 1992.

30. Leela KV and Babu K: Study of biochemical parameters in amniotic fluid for assessment of foetal maturity in cases of nor-mal pregnancy. J Evid Based Med Hlthcar 3: 8394-8399, 2016.

31. Gagnon R, Harding R and Brace R: Amniotic fluid and fetal urinary responses to severe placental insufficiency in sheep. Am J Obstet Gynecol 186: 1076-1084, 2002.

32. Gómez de la F CL, Novoa P JM and Caviedes R N: Bartter syndrome: An infrequent tubulopathy of prenatal onset. Rev Chil Pediatr 90: 437-442, 2019 (In English, Spanish).

33. Tong XL, Wang L, Gao TB, Qin YG, Qi YQ and Xu YP: Potential function of amniotic fluid in fetal development-novel insights by comparing the composition of human amniotic fluid with umbilical cord and maternal serum at mid and late gestation. J Chin Med Assoc 72: 368-373, 2009.

34. Sabatier M, Garcia-Rodenas CL, Castro CA, Kastenmayer P, Vigo M, Dubascoux S, Andrey D, Nicolas M, Payot JR, Bordier V, et al: Longitudinal changes of mineral concentrations in preterm and term human milk from lactating swiss women. Nutrients 11: 1855, 2019.

35. Cruikshank DP, Pitkin RM, Reynolds WA, Williams GA and Hargis GK: Calcium-regulating hormones and ions in amniotic fluid. Am J Obstet Gynecol 136: 621-625, 1980

36. Shah MC, Modi UJ, Bhatt RV and Mistry KP: Amniotic fluid composition in abnormal pregnancies. Indian $\mathrm{J}$ Pediatr 50: 271-274, 1983.

37. Pettit BR, Baker SP and King GS: The composition of amniotic fluid in pregnancies complicated by fetal anencephaly or Spina Bifida. Br J Obstet Gynaecol 86: 637-641, 1979.

38. Mimouni F, Miodovnik M, Tsang RC, Callahan J and Shaul P: Decreased amniotic fluid magnesium concentration in diabetic pregnancy. Obstet Gynecol 69: 12-14, 1987.

39. Gortzak-Uzan L, Mezad D, Smolin A, Friger M, Huleihel M and Hallak M: Increasing amniotic fluid magnesium concentrations with stable maternal serum levels: A prospective clinical trial. J Reprod Med 50: 817-820, 2005.

40. Hovdenak $\mathrm{N}$ and Haram K: Influence of mineral and vitamin supplements on pregnancy outcome. Eur J Obstet Gynecol Reprod Biol 164: 127-132, 2012.

41. Adama van Scheltema PN, In't Anker PS, Vereecken A, Vandenbussche FP, Kanhai HH and Devlieger R: Biochemical composition of amniotic fluid in pregnancies complicated with twin-twin transfusion syndrome. Fetal Diagn Ther 20: 186-189, 2005.

42. Correia-Branco A, Rincon MP, Pereira LM and Wallingford MC: Inorganic phosphate in the pathogenesis of pregnancy-related complications. Int J Mol Sci 21: 5283, 2020.

43. Schlievert P, Johnson W and Galask RP: Bacterial growth inhibition by amniotic fluid. VII. The effect of zinc supplementation on bacterial inhibitory activity of amniotic fluids from gestation of 20 weeks. Am J Obstet Gynecol 127: 603-608, 1977.

44. Tomblin J, Davis B and Larsen B: Phosphate content of human amniotic fluid and its relationship to bacterial growth inhibition. Am J Reprod Immunol Microbiol 13: 33-35, 1987.

45. Pier SM: The role of heavy metals in human health. Tex Rep Biol Med 33: 85-106, 1975

46. Chowdhury R, Ramond A, O'Keeffe LM, Shahzad S, Kunutsor SK, Muka T, Gregson J, Willeit P, Warnakula S, Khan $\mathrm{H}$, et al: Environmental toxic metal contaminants and risk of cardiovascular disease: Systematic review and meta-analysis. BMJ 362: k3310, 2018.

47. Kim DW, Ock J, Moon KW and Park CH: Association between $\mathrm{Pb}, \mathrm{Cd}$, and $\mathrm{Hg}$ exposure and liver injury among Korean adults. Int J Environ Res Public Health 18: 6783, 2021. 
48. Liu YH, Wang CW, Wu DW, Lee WH, Chen YC, Li CH, Tsai CC Lin WY, Chen SC, Hung CH, et al: Association of heavy metals with overall mortality in a Taiwanese population. Nutrients 13 : 2070, 2021

49. Durá Travé T, da Cunha Ferreira RM, Monreal I Ezcurdia Gurpegui $\mathrm{M}$ and Villa-Elizaga I: Zinc concentration of amniotic fluid in the course of pregnancy and its relationship to fetal weight and length. Gynecol Obstet Invest 18: 152-155, 1984.

50. Kumar V,Kumar A, Singh K, Avasthi K and Kim JJ: Neurobiology of zinc and its role in neurogenesis. Eur J Nutr 60: 55-64, 2021.

51. Boskabadi H, Maamouri G, Akhondian J, Ashrafzadeh F, Boskabadi A, Faramarzi R, Heidar E, Pourbadakhshan N, Shojaei SRH, Zakerihamidi M, et al: Comparison of birth weights of neonates of mothers receiving vs. not receiving zinc supplement at pregnancy. BMC Pregnancy Childbirth 21: 187, 2021.

52. Vickram S, Rohini K, Srinivasan S, Nancy Veenakumari D, Archana K, Anbarasu K, Jeyanthi P, Thanigaivel S, Gulothungan G, Rajendiran N and Srikumar PS: Role of zinc (Zn) in human reproduction: A journey from initial spermatogenesis to childbirth. Int J Mol Sci 22: 2188, 2021.

53. Jankovic-Karasoulos T, McAninch D, Dixon C, Leemaqz SY, François M, Leifert WR, McCullough D, Ricciardelli C, Roberts CT and Bianco-Miotto T: The effect of zinc on human trophoblast proliferation and oxidative stress. J Nutr Biochem 90: 108574, 2021.

54. Vetchý MPJVKKD: Biological role of copper as an essential trace element in the human organism. Ceska Slov Farm 67: 143-153, 2018

55. Lisa SH, Akhter QS, Nessa A, Munna MA and Eza LH: Serum copper level and its relation with blood pressure and urinary protein level in preeclampsia. Mymensingh Med J 30: 473-477, 2021.

56. Sak S, Barut M, Çelik H, Incebiyik A, Ağaçayak E, Uyanikoglu H, Kirmit A and Sak M: Copper and ceruloplasmin levels are closely related to the severity of preeclampsia. J Matern Fetal Neonatal Med 33: 96-102, 2020.

57. Schaefer M and Gitlin JD: Genetic disorders of membrane transport. IV. Wilson's disease and Menkes disease. Am J Physiol 276 G311-G314, 1999.

58. Tümer Z, Tønnesen T, Böhmann J, Marg W and Horn N: First trimester prenatal diagnosis of Menkes disease by DNA analysis. J Med Genet 31: 615-617, 1994

59. Gu YH, Kodama H, Sato E, Mochizuki D, Yanagawa Y, Takayanagi M, Sato K, Ogawa A, Ushijima $\mathrm{H}$ and Lee CC: Prenatal diagnosis of Menkes disease by genetic analysis and copper measurement. Brain Dev 24: 715-718, 2002.

60. Lorincz MT: Wilson disease and related copper disorders. Handb Clin Neurol 147: 279-292, 2018

61. Satish K and Trivedi AV: A Review on role of nickel in the biological system. Int J Curr Microbiol App Sci 5: 719-727, 2016.

62. Savolainen H: Biochemical and clinical aspects of nickel toxicity. Rev Environ Health 11: 167-173, 1996.

63. Zambelli B and Ciurli S: Nickel and human health. Met Ions Life Sci 13: 321-357, 2013

64. Moradnia M, Attar HM, Heidari Z, Mohammadi F and Kelishadi R: Prenatal exposure to chromium $(\mathrm{Cr})$ and nickel (Ni) in a sample of Iranian pregnant women: Urinary levels and associated socio-demographic and lifestyle factors. Environ Sci Pollut Res Int 28: 63412-63421, 2021.

65. Wang XW, Gu JY, Li Z, Song YF, Wu WS and Hou YP Gestational age and dose influence on placental transfer of $63 \mathrm{~N}$ in rats. Placenta 31: 305-311, 2010

66. Hou YP, Gu JY, Shao YF, Song YF, Jing YH, Wu WS and Pu S The characteristics of placental transfer and tissue concentrations of nickel in late gestational rats and fetuses. Placenta 32 277-282, 2011

67. Kakhlon OR and Cabantchik ZI: The labile iron pool: Characterization, measurement, and participation in cellular processes(1). Free Radic Biol Med 33: 1037-1046, 2002

68. Ganz T: Hepcidin, a key regulator of iron metabolism and mediator of anemia of inflammation. Blood 102: 783-788, 2003.

69. Trumbo P, Yates AA, Schlicker S and Poos M: Dietary reference intakes: Vitamin A, vitamin K, arsenic, boron, chromium, copper, iodine, iron, manganese, molybdenum, nickel, silicon, vanadium, and zinc. J Am Diet Assoc 101: 294-301, 2001.

70. Taylor CL and Brannon PM: Introduction to workshop on iron screening and supplementation in iron-replete pregnant women and young children. Am J Clin Nutr 106 (Suppl 6): 1547S-1554S, 2017.
71. Milman N: Iron in pregnancy: How do we secure an appropriate iron status in the mother and child? Ann Nutr Metab 59: 50-54, 2011.

72. Chigladze M: The predictive value of the mother's risk factors in formation of fetal developmental delay. Glob Pediatr Health 8: 2333794X21999149, 2021.

73. Fisher AL, Sangkhae V, Presicce P, Chougnet CA, Jobe AH, Kallapur SG, Tabbah S, Buhimschi CS, Buhimschi IA, Ganz T and Nemeth E: Fetal and amniotic fluid iron homeostasis in healthy and complicated murine, macaque, and human pregnancy. JCI Insight 5: e135321, 2020.

74. Gulec S, Anderson GJ and Collins JF: Mechanistic and regulatory aspects of intestinal iron absorption. Am J Physiol Gastrointest Liver Physiol 307: G397-G409, 2014

75. Burke RM, Leon JS and Suchdev PS: Identification, prevention and treatment of iron deficiency during the first 1000 days. Nutrients 6: 4093-4114, 2014

76. Bacon BR, Adams PC, Kowdley KV, Powell LW and Tavill AS; American Association for the Study of Liver Diseases: Diagnosis and management of hemochromatosis: 2011 practice guideline by the American association for the study of liver diseases. Hepatology 54: 328-343, 2011.

77. Wessling-Resnick M: Excess iron: Considerations related to development and early growth. Am J Clin Nutr 106 (Suppl 6): 1600S-1605S, 2017.

78. Tellez-Plaza M, Guallar E, Howard BV, Umans JG, Francesconi KA, Goessler W, Silbergeld EK, Devereux RB and Navas-Acien A: Cadmium exposure and incident cardiovascular disease. Epidemiology 24: 421-429, 2013.

79. Tellez-Plaza M, Jones MR, Dominguez-Lucas A, Guallar E and Navas-Acien A: Cadmium exposure and clinical cardiovascular disease: A systematic review. Curr Atheroscler Rep 15: 356, 2013.

80. Skolarczyk J, Pekar J, Skórzyńska-Dziduszko K and Łabądź D: Role of heavy metals in the development of obesity: A review of research. J Elem 23: 1271-1280, 2018.

81. Dobrescu A, Copaescu C,Zmeu B, Duta C, Bedreag OH, Stoica L, Tarta C, Rogobete AF and Lazar F: Ghrelin levels and hunger sensation after laparoscopic sleeve gastrectomy compared with laparoscopic greater curvature plication in obese patients. Clin Lab 66, 2020.

82. Luevano J and Damodaran C: A review of molecular events of cadmium-induced carcinogenesis. J Environ Pathol Toxicol Oncol 33: 183-194, 2014.

83. Joseph P: Mechanisms of cadmium carcinogenesis. Toxicol Appl Pharmacol 238: 272-279, 2009.

84. Liu J, Zeng L, Zhuang S, Zhang C, Li Y, Zhu J and Zhang W: Cadmium exposure during prenatal development causes progesterone disruptors in multiple generations via steroidogenic enzymes in rat ovarian granulosa cells. Ecotoxicol Environ Saf 201: 110765, 2020

85. Yi SJ, Xiong YW, Zhu HL, Dai LM, Cao XL, Liu WB, Shi XT, Zhou GX, Liu AY, Zhao LL, et al: Environmental cadmium exposure during pregnancy causes diabetes-like phenotypes in mouse offspring: Association with oxidative stress in the fetal liver. Sci Total Environ 777: 146006, 2021.

86. Zhu J, Huang Z, Yang F, Zhu M, Cao J, Chen J, Lin Y, Guo S, Li $\mathrm{J}$ and Liu Z: Cadmium disturbs epigenetic modification and induces DNA damage in mouse preimplantation embryos. Ecotoxicol Environ Saf 219: 112306, 2021.

87. Liao Y, Zheng H, Wu L, He L, Wang Y, Ou Y, Yang H, Peng S, Chen F, Wang $\mathrm{X}$ and Zhao J: Cadmium cytotoxicity and possible mechanisms in human trophoblast HTR-8/SVneo cells. Environ Toxicol 36: 1111-1124, 2021.

88. Amegah AK, Sewor C and Jaakkola JJK: Cadmium exposure and risk of adverse pregnancy and birth outcomes: A systematic review and dose-response meta-analysis of cohort and cohort-based case-control studies. J Expo Sci Environ Epidemiol 31: 299-317, 2021.

89. Gonzalez-Nahm S, Nihlani K, S House J, L Maguire R, $\mathrm{G}$ Skinner $\mathrm{H}$ and Hoyo $\mathrm{C}$ : Associations between maternal cadmium exposure with risk of preterm birth and low after birth weight effect of mediterranean diet adherence on affected prenatal outcomes. Toxics 8: 90, 2020.

90. Kaur M, Sharma P, Kaur R and Khetarpal P: Increased incidence of spontaneous abortions on exposure to cadmium and lead: A systematic review and meta-analysis. Gynecol Endocrinol 25: $1-6,2021$

91. Chan TF, Su JH, Chung YF, Hsu YH, Yeh YT, Jong SB and Yuan SS: Amniotic fluid and maternal serum leptin levels in pregnant women who subsequently develop preeclampsia. Eur J Obstet Gynecol Reprod Biol 108: 50-53, 2003. 
92.Akhtar E, Roy AK, Haq MA, von Ehrenstein OS, Ahmed S, Vahter M, Ekstrom EC, Kippler M, Wagatsuma Y and Raqib R: A longitudinal study of rural Bangladeshi children with long-term arsenic and cadmium exposures and biomarkers of cardiometabolic diseases. Environ Pollut 271: $116333,2021$.

93. Hunter P: A toxic brew we cannot live without, Micronutrients give insights into the interplay between geochemistry and evolutionary biology. EMBO Rep 9: 15-18, 2008.

94. Uthus EO: Evidence for arsenic essentiality. Environ Geochem Health 14: 55-58, 1992

95. Platanias LC: Biological responses to arsenic compounds. J Biol Chem 284: 18583-18587, 2009.

96. Wisessaowapak C, Watcharasit P and Satayavivad J: Arsenic disrupts neuronal insulin signaling through in-creasing free PI3K-p85 and decreasing PI3K activity. Toxicol Lett 349: 40-50, 2021

97. Navas-Acien A and Guallar E: Measuring Arsenic Exposure, Metabolism, and Biological effects: The role of urine proteomics. Toxicol Sci 106: 1-4, 2008

98. Wang SX, Wang ZH, Cheng XT, Li J, Sang ZP, Zhang XD, Han LL, Qiao XY, Wu ZM and Wang ZQ: Arsenic and fluoride exposure in drinking water: Children's IQ and growth in Shanyin county, Shanxi province, China. Environ Health Perspect 115 643-647, 2007.

99. Skogheim TS, Weyde KVF, Engel SM, Aase H, Surén P, Øie MG, Biele G, Reichborn-Kjennerud T, Caspersen IH, Hornig M, et al: Metal and essential element concentrations during pregnancy and associations with autism spectrum disorder and attention-deficit/hyperactivity disorder in children. Environ Int 152: 106468, 2021.

100. Vahter M: Effects of arsenic on maternal and fetal health. Annu Rev Nutr 29: 381-399, 2009.

101. Farzan SF, Chen Y, Wu F, Jiang J, Liu M, Baker E, Korrick SA and Karagas MR: Blood pressure changes in relation to arsenic exposure in a US pregnancy cohort. Environ Health Perspect 123: 999-1006, 2015.

102. Ekong EB, Jaar BG and Weaver VM: Lead-related nephrotoxicity: A review of the epidemiologic evidence. Kidney Int 70 2074-2084, 2006

103. Navas-Acien A, Guallar E, Silbergeld EK and Rothenberg SJ: Lead exposure and cardiovascular disease-a systematic review. Environ Health Perspect 115: 472-482, 2007.

104. Park SK, O'Neill MS, Vokonas PS, Sparrow D, Wright RO, Coull B, Nie H, Hu H and Schwartz J: Air pollution and hear rate variability: Effect modification by chronic lead exposure. Epidemiology 19: 111-120, 2008.

105. White LD, Cory-Slechta DA, Gilbert ME, Tiffany-Castiglioni E Zawia NH, Virgolini M, Rossi-George A, Lasley SM, Qian YC and Basha MR: New and evolving concepts in the neurotoxicology of lead. Toxicol Appl Pharmacol 225: 1-27, 2007.

106. Bouchard MF, Bellinger DC, Weuve J, Matthews-Bellinger J, Gilman SE, Wright RO, Schwartz J and Weisskopf MG: Blood lead levels and major depressive disorder, panic disorder, and generalized anxiety disorder in US young adults. Arch Gen Psychiatry 66: 1313-1319, 2009.

107. Meyer PA, McGeehin MA and Falk H: A global approach to childhood lead poisoning prevention. Int J Hyg Environ Health 206: 363-369, 2003.

108. Lanphear BP, Hornung R, Khoury J, Yolton K, Baghurst P, Bellinger DC, Canfield RL, Dietrich KN, Bornschein R, Greene T, et al: Low-level environmental lead exposure and children's intellectual function: An international pooled analysis. Environ Health Perspect 113: 894-899, 2005.

109. Bellinger DC: Very low lead exposures and children's neurodevelopment. Curr Opin Pediatr 20: 172-177, 2008.

110. Saylor C, Tamayo-Ortiz M, Pantic I, Amarasiriwardena C, McRae N, Estrada-Gutierrez G, Parra-Hernandez S, Tolentino MC, Baccarelli AA, Fadrowski JJ, et al: Prenatal blood lead levels and reduced preadolescent glomerular filtration rate: Modification by body mass index. Environ Int 154: 106414, 2021.
111. Hsieh CY, Jung CR, Lin CY and Hwang BF: Combined exposure to heavy metals in $\mathrm{PM}_{2.5}$ and pediatric asthma. J Allergy Clin Immunol 147: 2171-2180 e13, 2021.

112. Wang M, Xia W, Zeng Q, Zhang W, Qian X, Bao S, Zhou A, $\mathrm{Li} \mathrm{Y}$ and Xu S: Associations between prenatal and postnatal lead exposure and preschool children humoral and cellular immune responses. Ecotoxicol Environ Saf 207: 111536, 2021.

113. Lee S, Park SK, Park H, Lee W, Kwon JH, Hong YC, Ha M, Kim Y, Lee B and Ha E: Prenatal heavy metal exposures and atopic dermatitis with gender difference in 6-month-old infants using multipollutant analysis. Environ Res 195: 110865, 2021.

114. Bellinger DC: Teratogen update: Lead and pregnancy. Birth Defects Res A Clin Mol Teratol 73: 409-420, 2005

115. Goto Y, Mandai M, Nakayama T, Yamazaki S, Nakayama SF, Isobe T, Sato T and Nitta H: Association of prenatal maternal blood lead levels with birth outcomes in the Japan Environment and Children's Study (JECS): A nationwide birth cohort study. Int J Epidemiol 50: 156-164, 2021

116. Wu SZ, Xu HY, Chen Y, Chen Y, Zhu QL, Tan MH and Zhang MM: Association of blood lead levels with preeclampsia: A cohort study in China. Environ Res 195: 110822, 2021.

117. Irwinda R, Wibowo $\mathrm{N}$ and Putri AS: The concentration of micronutrients and heavy metals in maternal serum, placenta, and cord blood: A cross-sectional study in preterm birth. J Pregnancy 2019: 5062365, 2019.

118. Park J, Kim J, Kim E, Kim WJ and Won S: Prenatal lead exposure and cord blood DNA methylation in the Korean Exposome Study. Environ Res 195: 110767, 2021.

119. Tatsuta N, Nakai K, Kasanuma Y, Iwai-Shimada M, Sakamoto M, Murata K and Satoh H: Prenatal and postnatal lead exposures and intellectual development among 12-year-old Japanese children. Environ Res 189: 109844, 2020.

120. Tomska N, Kosik-Bogacka DI, Łanocha-Arendarczyk N, Szylińska A, Kotfis K, Sipak-Szmigiel O and Rotter I: Relationship between concentrations of elements and geographic location in Poland. Ann Agric Environ Med 28: 283-290, 2021.

121. Khanam R, Kumar I, Oladapo-Shittu O, Twose C, Islam AA, Biswal SS, Raqib R and Baqui AH: Prenatal environmental metal exposure and preterm birth: A scoping review. Int J Environ Res Public Health 18: 573, 2021.

122. Szukalska M, Merritt TA, Lorenc W, Sroczyńska K, Miechowicz I, Komorowicz I, Mazela J, Barałkiewicz D and Florek E: Toxic metals in human milk in relation to tobacco smoke exposure. Environ Res 197: 111090, 2021

123. Karakis I, Landau D, Gat R, Shemesh N, Tirosh O, Yitshak-Sade M, Sarov B and Novack L: Maternal metal concentration during gestation and pediatric morbidity in children: An exploratory analysis. Environ Health Prev Med 26: 40, 2021.

124. Riaz M, Lewis S, Naughton F and Ussher M: Predictors of smoking cessation during pregnancy: A systematic review and meta-analysis. Addiction 113: 610-622, 2018.

125. Gomez-Roig MD, Marchei E, Sabra S, Busardò FP, Mastrobattista L, Pichini S, Gratacós E and Garcia-Algar O: Maternal hair testing to disclose self-misreporting in drinking and smoking behavior during pregnancy. Alcohol 67: 1-6, 2018

126. Benowitz NL, Hukkanen J and Jacob P III: Nicotine chemistry, metabolism, kinetics and biomarkers. Handb Exp Pharmacol 29-60, 2009.

127. White AJ, O'Brien KM, Jackson BP and Karagas MR: Urine and toenail cadmium levels in pregnant women: A reliability study. Environ Int 118: 86-91, 2018.

This work is licensed under a Creative Commons Attribution-NonCommercial-NoDerivatives 4.0 International (CC BY-NC-ND 4.0) License. 